\title{
HPV-16/18 pozitif kadınların takibinde kolposkopi eşliğinde alınan servikal biyopsinin önemi
}

\author{
The importance of cervical biopsy taken under colposcopy in the follow-up of HPV- \\ 16/18 positive women
}

Soner Gök, Berfin Can Gök, Deniz Aydın Ceylan

\section{Özet}

Amaç: Sunulan çalışmada amacımız; servikal smear sitolojik incelemesiyle birlikte HPV taraması yapılan ve yüksek riskli HPV 16 veya HPV 18 pozitifliği saptanan hastalarda kolposkopi eşliğinde alınan servikal biyopsi ile sitoloji sonuçlarını karşılaştırmaktır.

Gereç ve yöntem: Çalışmaya; HPV 16 veya HPV 18 pozitifliği olup, 01/11/2018-20/09/2020 tarihleri arasında, kliniğimizde PAP smear ile birlikte kolposkopi eşliğinde servikal biyopsi alınan toplam 218 olgu dahil edilmiştir. Tüm olguların yaş, medeni durumu, sigara kullanımı, parite durumunu içeren demografik özellikleri, ayrıca PAP smear sonuçlarının biyopsi sonuçları ile ilişkisi retrospektif olarak incelenmiştir.

Bulgular: Demografik özelliklerden yalnızca yaş faktörünün biyopsi sonucu ile ilişkili olduğu gözlenmiştir $(p<0.05)$. Buna göre; in situ kanserler 41-50, invaziv kanserler 51-60 yaş grubunda yoğunlaşmaktadır. Sitolojisi benign olarak gelen 100 hastanın biyopsi sonuçları arasında 3 in situ ve 1 invaziv kanser tanısı mevcuttur. Toplam 3 invaziv kanserin geriye kalan iki tanesi ve 9 in situ kanserin yalnızca iki tanesi beklenen şekilde HSIL sitolojisi olan hastalara aittir. Yine kanser için ileri tetkik gerektiren bir sitolojik tanı olan ASC-H grubunda in situ kanserlerin yalnızca biri yer alırken, hiç invaziv kanser tanısı görülmemiştir.

Sonuç: Sunulan çalışma, kanser için yüksek risk teşkil eden HPV 16 veya 18 pozitif vakalarda PAP smear sonucu negatif olsa dahi kolposkopik incelemenin gerekliliğini desteklemektedir.

Anahtar kelimeler: İnsan papilloma virüs, kolposkopi, servikal biyopsi.

Soner Gök S, Can Gök B, Ceylan DA. HPV-16/18 pozitif kadınların takibinde kolposkopi eşliğinde alınan servikal biyopsinin önemi. Pam Tıp Derg 2021;14:253-261.

\begin{abstract}
Purpose: Our aim is to compare the results of cervical biopsy with colposcopy in patients who underwent HPV screening with cervical smear cytological examination and who were found to have high-risk HPV 16 or 18 positivity.

Materials and methods: A total of 218 patients with HPV 16 or HPV 18 positivity and who underwent both PAP smear and cervical biopsy accompanied by colposcopy, in our clinic between the dates of 01/11/201820/09/2020 were included in the study. The demographic characteristics of all cases including age, marital status, smoking, parity status, as well as the relationship between PAP smear results and biopsy results were analyzed retrospectively.

Results: Among the demographic features, only age factor was observed to be related to the biopsy result. According to this; in situ cancers were significantly higher in the 41-50 age group and invasive cancers were significantly higher in the 51-60 age group. Among the biopsy results of 100 patients with benign cytology, there were 3 in situ and 1 invasive cancer diagnosis. The remaining 2 of the 3 invasive cancers in total and only 2 of the 9 in situ cancers were in HSIL cytology group. In the ASC-H group, which is also a cytological diagnosis that requires further examination for cancer, only one of the in situ cancers took place, while no invasive cancer was diagnosed.

Conclusion: The present study supports the necessity of colposcopic examination in HPV 16 or 18 positive cases that pose a high risk for cancer, even if the PAP smear result is negative.
\end{abstract}

Key words: Human papilloma virus, colposcopy, cervical biopsy.

Soner Gok S, Can Gok B, Ceylan DA. The importance of cervical biopsy taken under colposcopy in the follow-up of HPV-16/18 positive women. Pam Med J 2021;14:253-261.

Soner Gök, Dr. Öğr. Üye. Pamukkale Üniversitesi Tıp Fakültesi, Kadın Hastalıkları ve Doğum Anabilim Dalı, Denizli, Türkiye, e-posta: sonerrgok@hotmail.com (orcid.org/0000-0001-8940-1879) (Sorumlu Yazar)

Berfin Can Gök, Uzm. Dr. Servergazi Devlet Hastanesi, Kadın Hastalıkları ve Doğum Kliniği, Denizli, Türkiye, e-posta: berfinyurdam@gmail. com (orcid.org/0000-0001-5739-3683)

Deniz Aydın Ceylan, Arş. Gör. Dr. Pamukkale Üniversitesi Tıp Fakültesi, Kadın Hastalıkları ve Doğum Anabilim Dalı, Denizli, Türkiye, e-posta: denizaydinceylan@gmail.com (orcid.org/0000-0001-8780-4084) 


\section{Giriş}

Servikal kanser; yılda 530 bin yeni vaka ve 270 bin ölüm oranı ile kadınlarda dünya genelinde en sık görülen dördüncü sıradaki malignitedir [1]. Servikal kansere bağlı ölümlerin yaklaşık \%90'ı az gelişmiş ve gelişmekte olan ülkelerde görülmektedir. Dağılımdaki bu coğrafik varyasyon, prekanseröz lezyonların tespiti ve ortadan kaldırılmasına izin veren taramaların kullanım imkanlarına ve toplumlarda insan papilloma virüsü (HPV) enfeksiyonu görülme oranlarına bağlı olarak ortaya çıkmaktadır [2, 3].

Servikal kanser vakalarının çoğu HPV enfeksiyonundan kaynaklanır ve malign servikal lezyonların yaklaşık \%95'inde HPV DNA'sı tanımlanmaktadır [4]. HPV, bazal epitel hücrelerini enfekte ederek anogenital ve üst solunum-sindirim kanalında deri ve mukozada iyi huylu ve kötü huylu lezyonlara neden olan bir DNA virüsü ailesini içerir [5]. HPV enfeksiyonlarının çoğu geçicidir ve kendiliğinden düzelir. Bununla birlikte, özellikle bazı türleri, p53 ve Retinoblastoma (Rb) gibi viral onkogenleri eksprese ederek genomik kararsızlığın artmasına, somatik mutasyonların birikmesine ve bazı durumlarda HPV' nin konak genomuna entegrasyonuna yol açarlar [6]. Bu sayede kronik enfeksiyon, servikal intraepitelyal neoplazi veya adenokarsinom in situ gibi premalign koşulların gelişmesine neden olabilirler. Epidemiyolojik çalışmalar sonucunda, HPV tip 16, 18, 31, 33, 35, 39, 45, 51, 52, 56,58 ve 59 'un kanserojen ve HPV tip 68'in muhtemel kanserojen olduğu bildirilmektedir [5, 7]. Tedavi olmaksızın, çoğu kadında displaziden invazif karsinomaya geçişin gelişmesi yıllar veya on yıllar alabilir. Ancak hastaların yaklaşık \%10'unda bu geçiş 1 yıldan daha az bir sürede gerçekleşebilir [8].

Papanicolaou (PAP) smear testi taraması, yaklaşık 30 yılda serviks kanseri insidansını \%50'ye varan oranda azaltmasına rağmen, serviks kanseri kadınlarda halen kanser ölümlerinde ön sıralarda yer almaktadır. Servikste potansiyel olarak prekanseröz ve kanseröz hücreleri tespit etmek için kullanılan çok başarılı bir tarama testi olan PAP smear değerlendirilmesinde Bethesda sistemi kullanılmaktadır. Ancak PAP smear'in nispeten düşük sensitivitesi (\%50 civarı), bazı durumlarda yetersiz spesmen problemi yaşanması ve Bethesda sisteminde yer alan bazı kategorilerde takip konusunda yaşanan sorunlar nedeniyle PAP test bazen yetersiz kalabilmektedir [2]. Bu nedenle servikal kanserin erken teşhisinde ve önlenmesinde kişideki HPV enfeksiyonunun ve buna neden olan HPV tipinin saptanması önem taşımaktadır. Özellikle yüksek riskli HPV tespit edilmesi durumunda bu hastaların daha yakın takibi, ya da cerrahi müdahalesine karar verilebilmektedir. HPV ilişkili neoplastik değişiklikler invaziv kanser gelişmeden önce servikal intraepitelyal neoplazi (CIN) olarak başlar. $\mathrm{CIN}-1$ olarak başlamasının ardından CIN-2 ve CIN-3'e ilerler. Genel olarak derece ne kadar yüksek ise invaziv kanser gelişme riski o kadar yüksektir. Bu derecelendirme sistemi; $\mathrm{CIN}-1$ için düşük dereceli skuamoz intraepitelyal neoplazi (Low-SIL), CIN-2 ve CIN-3 için yüksek dereceli intraepitelyal neoplazi (HighSIL) olmak üzere iki grupta sınıflandırılarak klinik ve patolojik açıdan daha basit bir hale getirilmiştir. Low-SIL için klinik takip önerilirken, High-SIL için cerrahi müdahale seçeneği değerlendirilmektedir [9]. Anormal smear bulgusu veya yüksek riskli HPV varlığında; kesin patolojik sonucun elde edilmesinde, lezyonun boyut ve lokalizasyonunun saptanmasında ve aynı zamanda terapötik amaçlı olarak kolposkopik inceleme yapılmakta ve gerekirse bu incelemede biyopsi veya eksizyonel prosedürler uygulanabilmektedir [10].

Sunulan çalışmamızda yaygın bir kadın sağlığı sorunu olan servikal kanserlerin erken teşhis ve takibine katkı sağlama amacıyla servikal kanser oluşturma potansiyeli en yüksek olan yüksek riskli HPV 16 veya HPV 18 pozitifliği saptanan kadınlarda servikal sitoloji ile kolposkopi eşliğinde alınan servikal biyopsi sonuçlarını karşılaştırarak literatüre katkı sağlamayı amaçlamaktayız.

\section{Gereç ve yöntem}

\section{Olgular}

Çalışmamı Pamukkale Üniversitesi Girişimsel Olmayan Klinik Araştırmalar Etik Kurulu'nun onayının alınması sonrasında başlatılmıştır. Çalışmaya; HPV 16, HPV 18 veya her ikisinin pozitifliği olan, 01/11/201820/09/2020 tarihleri arasında hastanemizde PAP smear sonuçları ile birlikte kolposkopi eşliğinde servikal biyopsi alınan toplan 218 olgu dahil edilmiştir. HPV 16 ve HPV 18 dışındaki HPV tipleri veya başka bir nedenle 
kolposkopi veya serviks biyopsisi alınan olgular çalışmaya dahil edilmemiştir. Retrospektif olan bu çalışmamızda çalışmaya dahil edilen tüm olguların yaş, medeni hali, sigara kullanımı, parite gibi demografik özellikleri, HPV tipi, smear ve biyopsi sonuçlarına girişimsel işlem kayıt defteri ve HBYS sistemi üzerinden ulaşılmıştır.

Hastalar 20-30 yaş, 31-40 yaş, 41-50 yaş, 51-60 yaş ve 61 yaş üstü olmak üzere 5 gruba ayrıldı. Servikal sitoloji sonuçları benign, ASCUS, Low-SIL, High-SIL, ASC-H olarak gruplara ayrıldı. Kliniğimizde smear alınan hastaların foliküler dönemde olmasına, testten 3 gün öncesi ilişki ve vajinal duş uygulamasının olmamasına, vajinal fitil, krem, jel gibi bir ajanın kullanılmamış olmasına dikkat edilmektedir. Çok yoğun akıntısı olan hastalar tedavi sonrası smear testi için çağrılmaktadır. Hastalardan alınan servikal sürüntü örnekleri Bethesda sistemine göre değerlendirilmesi yapılıp raporlanmaktadır.

Kolposkopik muayenede serviks serum fizyololojik ile yıkandıktan sonra atipik damarlanma açısından yeşil filtre ile incelenmektedir. Sonrasında \%5 asetik asit ile asetowhite alan varlığı araştırılmaktadır. Lugol solusyonu ile de serviks boyanarak lugol tutulumu olmayan alanlar tespit edilmektedir. Patolojik bulguların izlendiği alanlara göre punch veya LEEP işlemi ile biyopsiler alınmaktadır. Patolojik görünüm tespit edilemeyen hastalarda ise 4 kadran (saat 12, 3, 6, 9 hizasından) kontrol biyopsisi alınmaktadır.

\section{İstatiksel analiz yöntemi}

Veriler SPSS paket programılla analiz edilmiştir. Sürekli değişkenler ortalama \pm standart sapma ve kategorik değişkenler sayı ve yüzde olarak verilmiştir. Parametrik test varsayımları sağlandığında bağımsız grup farklıııkların karşılaştııılmasında İki Ortalama Arasındaki Farkın Önemlilik Testi ve Tek Yönlü Varyans Analizi; parametrik test varsayımları sağlanmadığında ise bağımsız grup farklılıkların karşılaştırılmasında Mann-Whitney $U$ testi ve Kruskal Wallis Varyans Analizi kullanıımıştır. Ayrıca sürekli değişkenlerin arasındaki ilişkiler Spearman ya da Pearson korelasyon analizleriyle ve kategorik değişkenler arasındaki farklııklar ise Ki kare analizi ile incelenmiştir. Bağımlı değişkenler ile ilişkili faktörlerin incelenmesinde ise uygun regresyon modelleri kullanılmıştır.

\section{Bulgular}

Tablo 1'de hastalara ait tanımlayıcı istatistikler verilmiştir. Çalışmaya dahil edilen katıımcıların \%80,3'ü evli olduğu; $\% 68,8$ 'nin sigara kullanmadığı tespit edilmiştir. Katılımcılardan \%10,6'nın 20-30 yaş aralığında, $\% 29,4$ 'ünün 31-40 yaş, \%6'nın ise 61 ve üzeri yaşında olduğu tespit edilmiştir. Katılımcıların çoğunluğunun parite $2(\% 35,3)$ ve parite 3 (\%22) derecesinde oldukları belirlenmiştir. Tablo'ya göre hastaların \%67,9'nun HPV 16, \%20,6'nın HPV 18 ve \%11,5'nin HPV 16 ve 18 olduğu tespit edilmiştir. Smear sonuçlarına göre hastaların \%45,9'nun benign, \%26,6'nın ASCUS, \%16,1'nin LSIL, \%9,6'nın HSIL ve $\% 1,8$ 'nin ise ASC-H olduğu belirlendi. Hastaların \%32,1'inde Punch, \%67,9'da Loop Electrosurgical Excision Procedure (LEEP) biyopsi yöntemi uygulanmıştır.

Tablo 2'de medeni hal, sigara kullanımı ve parite ile biyopsi sonuçları verilmiştir. Tablo'ya göre medeni durum ile biyopsi sonuçları arasında anlamlı bir ilişki olmadığı tespit edilmiştir $(p>0,05)$. Bekarların \%51,2'nin kronik servisit, \%18,6'nın CIN-1 ve \%23,3'nün CIN3 olduğu; evlilerin \%46,9'nun kronik servisit, \%13,1'nin CIN-1, \%24'nün ise CIN-3 olduğu görülmektedir. Yine sigara kullanımı ve parite ile biyopsi sonuçları arasında herhangi bir anlamlılık tespit edilmemiştir $(p>0,05)$.

Tablo 3'de ise Klinik değişkenler ile biyopsi sonuçlarının ilişkisi gösterilmektedir. Buna göre yaş ile biyopsi sonuçları arasında anlamlılık olduğu tespit edilmiştir $(p<0,05)$. 20-30, 3140 ve 41-50 yaş aralıklarında kronik servisit görülme oranı anlamlı derecede yüksek iken 51-60 yaş aralığında CIN-3 biyopsi sonuçlarının daha yüksek oranda olduğu görülmektedir. HPV tipi ile biyopsi sonuçları arasında istatistiksel bir anlamlılık bulunmamıştır. Smear sonucu benign, ASCUS ve LSIL olanların biyopsi sonuçlarında kronik servisit (sırasıyla \%58, \%58,6 ve $\% 31,4$ ) ve CIN-3 (sırasıyla \%20, \%17,2 ve \%28,6) görülme oranlarının daha yüksek olduğu gözlenmiştir. Smear sonucu HSIL olanlarda en fazla CIN-3 $(\% 52,4)$ biyopsi sonucu olduğu belirlenmiştir. Smear sonuçları ile biyopsi sonuçları arasındaki bu farkın istatistiksel olarak anlamlılık gösterdiği tespit edilmiştir $(p<0,05)$. 
Tablo 1. Hastalara ait tanımlayıcı istatistikler

\begin{tabular}{|c|c|c|c|}
\hline & & Sayı & Yüzde \\
\hline \multirow[t]{2}{*}{ Medeni hal } & Bekar & 43 & 19,7 \\
\hline & Evli & 175 & 80,3 \\
\hline \multirow[t]{2}{*}{ Sigara kullanımı } & Hayır & 150 & 68,8 \\
\hline & Evet & 68 & 31,2 \\
\hline \multirow[t]{5}{*}{ Yaş grubu (Yıl) } & $20-30$ & 23 & 10,6 \\
\hline & $31-40$ & 64 & 29,4 \\
\hline & $41-50$ & 81 & 37,2 \\
\hline & $51-60$ & 37 & 17,0 \\
\hline & 61 ve üzeri & 13 & 6,0 \\
\hline \multirow[t]{6}{*}{ Parite } & 0 & 42 & 19,3 \\
\hline & 1 & 24 & 11,0 \\
\hline & 2 & 77 & 35,3 \\
\hline & 3 & 48 & 22,0 \\
\hline & 4 & 20 & 9,2 \\
\hline & 5 & 7 & 3,2 \\
\hline \multirow[t]{3}{*}{ HPV tipi } & Hpv 16 & 148 & 67,9 \\
\hline & Hpv 18 & 45 & 20,6 \\
\hline & Hpv 16 ve 18 & 25 & 11,5 \\
\hline \multirow[t]{5}{*}{ Smear sonuç } & BENIGN & 100 & 45,9 \\
\hline & Ascus & 58 & 26,6 \\
\hline & LSIL & 35 & 16,1 \\
\hline & HSIL & 21 & 9,6 \\
\hline & ASC-H & 4 & 1,8 \\
\hline \multirow[t]{2}{*}{ Biyopsi yöntemi } & Punch & 70 & 32,1 \\
\hline & LEEP & 148 & 67,9 \\
\hline \multirow[t]{7}{*}{ Biyopsi sonuç } & Kronik servisit & 104 & 47,7 \\
\hline & CIN1 & 31 & 14,2 \\
\hline & CIN2 & 19 & 8,7 \\
\hline & CIN3 & 52 & 23,9 \\
\hline & İnsitu kanser & 9 & 4,1 \\
\hline & İnvaziv kanser & 3 & 1,4 \\
\hline & Total & 218 & 100,0 \\
\hline
\end{tabular}

HPV: Human papilloma virüs

ASCUS: Atipik skuamoz hücreler, önemi bilinmeyen

LSIL: Düşük dereceli servikal intraepitelyal lezyon

HSIL: Yüksek dereceli servikal intraepitelyal lezyon

ASC-H: Atipik skuamoz hücreler, yüksek derceli lezyonun ekarte edilemediği

CIN: Servikal intraepitelyal neoplazi; Leep: Loop electrosurgical excision procedure 


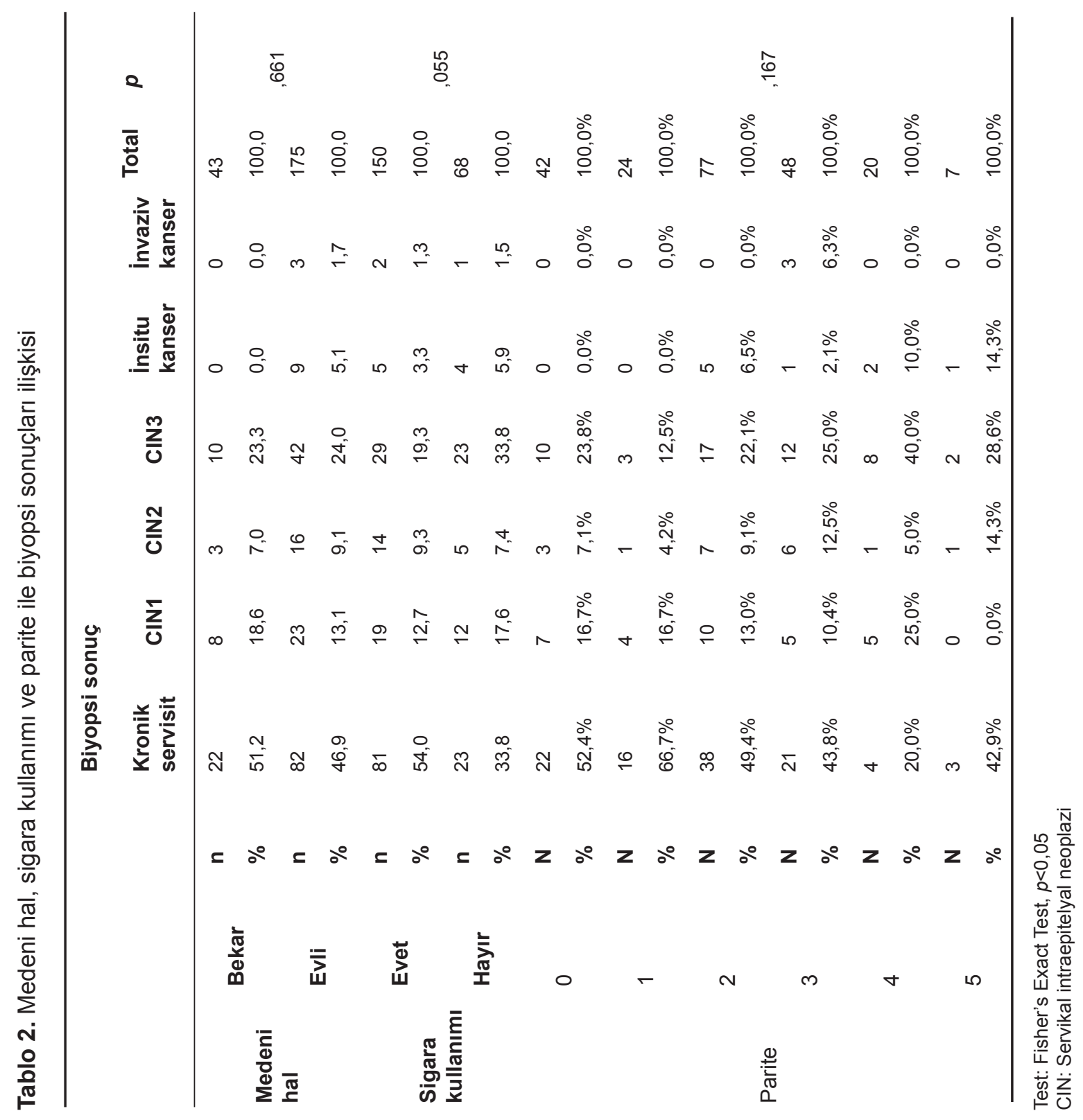


Tablo 3. Klinik değişkenler ile servikal biyopsi sonuçları arasındaki ilişki

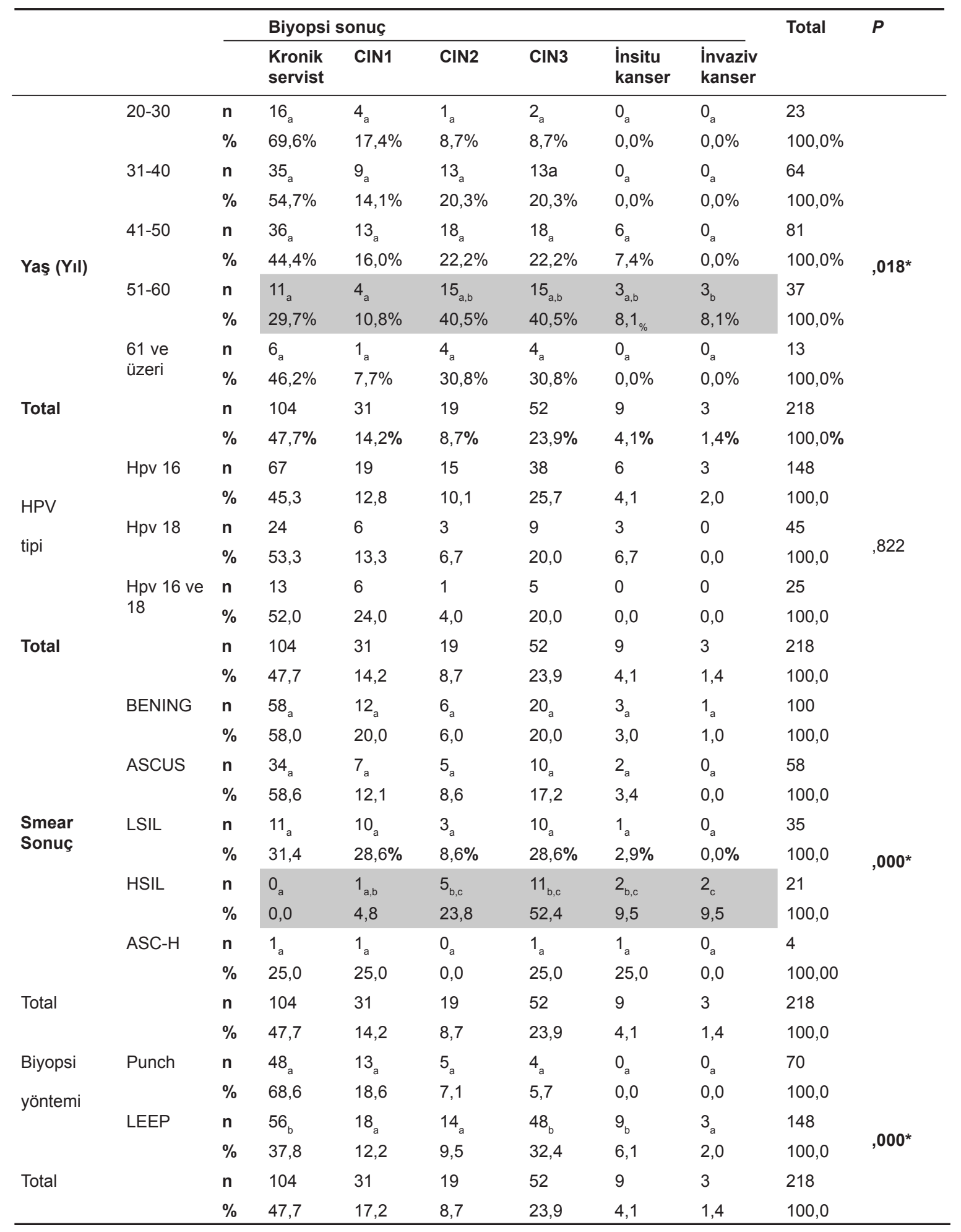

Test: Fisher's Exact Test, $p<0,05$

*Aynı harflerin bulunduğu sütunlar arasında fark bulunmamaktadır HPV: Human papilloma virüs

ASCUS: Atipik skuamoz hücreler, önemi bilinmeyen

LSIL: Düşük dereceli servikal intraepitelyal lezyon

HSIL: Yüksek dereceli servikal intraepitelyal lezyon

ASC-H: Atipik skuamoz hücreler, yüksek derceli lezyonun ekarte edilemediği

$\mathrm{CIN}$ : Servikal intraepitelyal neoplazi 
Yine Tablo 3'de biyopsi alma yöntemi ile biyopsi sonuçları arasındaki ilişki verilmiştir. Buna göre Punch biyopsi ile en fazla kronik servisit $(\% 68,6)$ ve CIN-1 $(\% 18,6)$ tespit edilmiştir. LEEP işlemi sonucunda da en fazla kronik servisit $(\% 37,8)$, sonra CIN-3 $(\% 32,4)$, daha sonra ise $\mathrm{CIN}-1(\% 12,2)$ belirlenmiştir. İn situ ve İnvaziv kanser tanılarının tamamı LEEP yöntemi ile konulmuştur.

\section{Tartışma}

Sunulan çalışmada; HPV 16 ve HPV 18 pozitif hastaların demografik özelliklerinin dağılımına baktığımızda; büyük çoğunluğunun evli, 31-50 yaş grubunda ve 2-3 pariteye sahip oldukları görülmektedir. Uzun yıllardır yapılan çalışmaların sonucunda, HPV enfeksiyonunun primer bulaş yolunun cinsel ilişki yolu ile olduğu bilinmektedir [11]. Katılımcılarımızın büyük çoğunluğunun evli ve 30 yaş üzerinde olması göz önüne alınarak, çalışmamızın verileri de bu durumu desteklemektedir. Hastalarda demografik özelliklerden yaş, sigara kullanımı, medeni durum ve paritenin biyopsi sonuçları ile ilişkisi incelendiğinde; yalnızca yaş faktörünün biyopsi sonucu ile ilişkili olduğu gözlenmiştir. Buna göre, tüm yaş gruplarında en yüksek oranda kronik servisit gözlemlenirken, bunu $\mathrm{CIN}-1$, CIN-2 ve CIN-3 tanıları takip etmekte, in situ ve invaziv kanserler ise en düşük payı almaktadır. Bununla birlikte, yaş ilerledikçe kronik servisit oranı düşerken, CIN-1, CIN-2 ve $\mathrm{CIN}-3$ oranları artmakta, in situ ve invaziv kanser görülme ihtimali de yükselmektedir. Çalışma grubumuzda in situ kanser olguları 41-50 yaş grubunda başlarken, invaziv kanser olgusu sadece 51-60 yaş grubunda görülmüştür. Bu da erken tanı ve tedavi şansı olmayan vakalarda progresif süreci göz önüne sermektedir. Literatürde sigara kullanımı ve gebelik sürecinin de servikste transformasyon zonundaki HPV enfeksiyonuna bağlı metaplastik aktiviteyi tetiklediği bildirilmekle beraber [12, 13], inflamasyondan maligniteye dönüşüm süreci oldukça uzun olduğundan çalışmamızın sonuçlarına yansımadığını düşünmekteyiz.

Hastalarımızın büyük çoğunluğunun $(\% 67,9)$ HPV tiplemesinin HPV 16 olduğu, HPV 18 ve kombine HPV 16-18 pozitifliğinin nispeten daha düşük oranlarda olduğunu görmekteyiz. Bugüne kadar 200'den fazla genotipi tanımlanmış olan HPV virüsünün karsinojen olduğu belirlenen 25 tipi arasında
HPV 16 ve 18 dikkat çekici oranda ön plana çıkmaktadır. Bununla birlikte; gerek sağlıklı, gerek servikal kanserli gerekse prekanseröz lezyonlu hastalarda HPV 16 insidansı diğer tüm genotiplere oranla daha yaygın olarak saptanmaktadır [14]. Dünya çapında 5 kıtadan normal servikal sitolojiye sahip 1 milyon kadının meta-analizinin yapıldığı bir çalışmada tahmin edilen küresel HPV prevalansı \%11,7, HPV 16 prevalansı $\% 3,2$ ve HPV 18 prevalansı $\% 1,4$ olarak raporlanmıştır [15]. Çalışmamızda elde edilen oranlar, literatürdeki verilerle uyumludur. Yine yapılan geniş kapsamlı çalışmalara göre, HPV 16 normal sitolojik bulgulara ve servikal intraepitelyal neoplaziye kıyasla invaziv servikal kanserde daha yüksek prevalansa sahiptir ve bunu HPV 18 izlemektedir [16]. Çalışmamızın zayıf yönü; biyopsi sonuçlarına göre HPV tiplerini karşılaştırdığımızda; 3 invaziv kanser olgusunun tamamı HPV 16+ hastalarda olmasına rağmen, sayının azlığı nedeni ile aralarında istatistiksel olarak anlamlı bir fark olmadığını görüyoruz. Daha geniş ölçekli bir çalışma ile desteklendiğinde, sonuçların güvenilirliği artacaktır.

Çalışmamızın bir diğer güçlü yanı ise, Papsmear sitoloji sonuçları ile biyopsi sonuçlarının karşılaştırılmasıdır. Buna göre; sitolojik incelemede en fazla benign lezyon tanısı koyulurken, sitolojisi benign olarak gelen 100 hastanın biyopsi sonuçları arasında 3 in situ ve 1 invaziv kanser tanısı mevcuttur. Toplam 3 invaziv kanserin geriye kalan iki tanesi ve 9 in situ kanserin yalnızca iki tanesi beklenen şekilde HSIL sitolojisi olan hastalara aittir. Yine kanser için ileri tetkik gerektiren bir sitolojik tanı olan ASC-H grubunda in situ kanserlerin yalnızca biri yer alırken, hiç invaziv kanser tanısı olmadığını görmekteyiz. Bu sonuçlar özellikle HPV 16 ve 18 + olup servikal kanser için risk grubuna dahil edilen hastalarda sitoloji sonucu ne olursa olsun servikal biyopsi yapılmalı mı sorusunu akla getirmektedir. Pap smear; cinsel olarak aktif hale geldikten sonra, kadınlara her 1 ila 5 yılda bir yaptırmaları tavsiye edilen bir tarama ve erken tanı testidir. Çeşitli çalışmalarda; servikal biyopsi baz alındığında, sitolojinin servikal neoplaziyi tespit etmede \%50 ila \%98 arasında değişen duyarlılığa sahip olabileceğini göstermektedir $[17,18]$. Sitolojide, prekanseröz ve kanseröz lezyonlar için yanlış negatif sonuçlar, hava ile kurutma ve fiksasyon artefaktı, inflamasyon ve hücresel detayların kanla gizlenmesi gibi teknik 
hatalar nedeniyle veya yetersiz örneklemeden kaynaklanabilmektedir [17]. Bu nedenle özellikle 30 yaş üzeri kadınlarda 3 defaya kadar belirli aralıklarla testin tekrarlanması önerilen bir alternatiftir [19]. Son yıllarda, HPV-16/18 genotipleme ile Cobas hrHPV testi, rahim ağzı kanseri taraması ve ASC-US'li hastalarda triyaj için Pap testi ile birlikte ek bir test olarak klinik uygulamada giderek daha fazla kullanılmaktadır [20]. HPV testi pozitif ve PAP smear testi negatif olan bir grup kadın için uyulması gereken strateji tartışmalıdır. 2012'de yayınlanan Amerikan Kolposkopi Derneği ve Servikal Patoloji Yönetim Kılavuzları'nda bu gruba PAP smear sonrası kolposkopik inceleme önerilmektedir [21].

$\mathrm{Bu}$ çalışmada üzerinde durulan bir diğer konu da uygulanan biyopsi yöntemidir. Hastalarımızın 70'ine punch biyopsi uygulanırken, 148'i LEEP biyopsi ile tanı almıştır. İki yöntemi karşılaştırdığımızda; punch biyopsi örneklerinde, ezilme artefaktları, mukozanın soyulması ve yeterli miktarda ve derinlikte anormal doku sağlanamaması gibi birçok faktör tatmin edici olmayan sonuçlara yol açabilirken, LEEP numunelerinin tanısal sorunları çoğunlukla termal hasardan kaynaklanır. Yapılan çalışmalarda karşılaştırmalı bulgular, tanı için kabul edilebilir bir doku örneği sağlamada her iki yöntemin birbirine herhangi bir üstünlük sağlamadığını ifade etmektedir [22]. Çalışmamızda tüm kanseröz lezyonların LEEP biyopsi ile yakalanması, bu yöntemin punch biyopsiye oranla iki kat fazla tercih edilmesinden kaynaklı olabilir. Kesin bir kanıya varılabilmesi için daha geniş örneklemli ileri çalışmalara intiyaç vardır.

Sonuç olarak; yapmış olduğumuz bu çalışmada kolposkopi eşliğinde servikal biyopsi alınan 218 olgunun 9 tanesinde $(\% 4,1)$ insitu kanser tespit edilmiş olup bunlardan 3 tanesinin $(\% 33,3)$ Pap smear sonucu benign grupta yer almaktaydı. Yine çalışmamızdaki 218 olgunun 3 tanesinde $(\% 1,4)$ invaziv kanser tespit edilmiş olup bunlardan 1 tanesinin $(\% 33,3)$ Pap smear sonucu benign grupta yer almaktaydı. Sunulan çalışma özellikle 30 yaş üzeri, servikal kanser için yüksek risk teşkil eden HPV 16-18 pozitif vakalarda PAP smear sonucu negatif olsa dahi premalign ve malign lezyonların varlığını tam olarak ekarte edemeyebileceğini, kolposkopik incelemenin gerekliliğini desteklemektedir.
Çıkar ilişkisi: Yazarlar çıkar ilişkilerinin olmadığını beyan ederler.

\section{Kaynaklar}

1. World Health Organization. Human papillomavirus (HPV) and cervical cancer. Available at: http://www. who.int/mediacentre/factsheets/fs380/en/. Accessed June 10, 2016

2. Marth C, Landoni F, Mahner S, McCormack M, Gonzalez Martin A, Colombo N. Cervical cancer: ESMO Clinical Practice Guidelines for diagnosis, treatment and follow-up. Ann Oncol 2017;28:72-83. https://doi.org/10.1093/annonc/mdx220

3. International Agency for Research on Cancer, EUCAN. Available at: http://eco.iarc.fr/eucan. Accessed April 29, 2017

4. Waggoner SE, Chernicky CL. Molecular biology of cervical and vulvar carcinoma. In: Gershenson DM, McGuire WP, Gore M, Quinn MA, Thomas G, eds. Gynaecologic Cancer: Controversies in Management. Philadelphia: Churchill Livingstone 2004:65-78. https:// doi.org/10.1016/B978-0-443-07142-3.X5001-5

5. IARC. Human Papillomaviruses. IARC Monogr Eval Carcinog Risks Hum 2007;90:1-670.

6. Moody CA, Laimins LA. Human papillomavirus oncoproteins: pathways to transformation. Nat Rev Cancer 2010;10:550-560. https://doi.org/10.1038/ nrc2886

7. De Martel C, Plummer M, Vignat J, Franceschi S. Worldwide burden of cancer attributable to HPV by site, countryand HPV type. 2017;141:664-670. https:// doi.org/10.1002/ijc.30716

8. National Cancer Institute. Cervical Cancer Treatment (PDQVR )-Health Professional Version. 2016 Available at: http://www.cancer.gov/types/cervical/hp/cervicaltreatment-pdq\#link/532_toc. Accessed August 20, 2020

9. Çoban Ö, Durukan H, Dilek TUK, Doruk A, Dilek S. Determination of recurrent/residual $\mathrm{CIN}$-II and CIN-III after leep. Cytologyor HPV-DNA? Zeynep Kamil Tıp Bülteni 2016;47:101-105. http://dx.doi.org/10.16948/ zktb.09286

10. Benedet JL, Matisic JP, Bertrand MA. An analysis of 84, 244 patients from the British Columbia cytologycolposcopy program. Gynecol Oncol 2004;92:127-134. https://doi.org/ 10.1016/j.ygyno.2003.10.001

11. Franco EL, Rohan TE, Villa LL. Epidemiologic evidence and human papillomavirus infection as a necessary cause of cervical cancer. J Natl Cancer Inst (JNCI) 1999;91:506-511. https://doi.org/10.1093/jnci/91.6.506

12. Mukhopadhyay S. A demographic and clinico pathological study of HPV associated cofactors in the pathogenesis of cervical cancer. Indian J Obstetr Gynecol Res 2019;6:472-479. http://doi.org/10.18231/j. ijogr.2019.103 
13. Castellsagué $X$, Muñoz N. Chapter 3: Cofactors in human papillomavirus carcinogenesis-role of parity, oral contraceptives, and tobacco smoking. J Natl Cancer Inst Monogr 2003;31:20-28. https://doi. org/10.1093/oxfordjournals.jncimonographs.a003477

14. De Sanjose S, Diaz M, Castellsague X, et al. Worldwide prevalence and genotype distribution of cervical human papillomavirus DNA in womenwith normal cytology: a meta-analysis. Lancet Infect Dis 2007;7:453-459. https://doi.org/10.1016/S1473-3099(07)70158-5

15. Bruni L, Diaz M, Castellsagué M, Ferrer E, Bosch FX, de Sanjosé S. Cervical human papillomavirus prevalence in 5 continents: meta-analysis of 1 million women with normal cytological findings. J Infect Dis 2010;202:1789-1799. https://doi.org/10.1086/657321

16. Clifford GM, Tully S, Franceschi S. Carcinogenicity of human papillomavirus (HPV) types in HIV-positive women: a meta-analysis from HPV infection to cervical cancer. Clin Infect Dis 2017;64:1228-1235. https://doi. org/10.1093/cid/cix135

17. Dhakal R, Makaju R, Sharma S, Bhandari S, Shrestha $S$, Bastakoti R. Correlation of cervical pap smear with biopsy in the lesion of cervix. Kathmandu Univ Med J (KUMJ) 2016;55:254-257.

18. Pradhan B, Pradhan SB, Mital VP. Correlation of pap smear findings with clinical findings and cervical biopsy. Kathmandu Univ Med J (KUMJ) 2007;5:461-467.

19. Moyer VA. US Preventive Services Task Force. Screening for cervical cancer: U.S. Preventive Services Task Force recommendation statement. Ann Intern Med 2012;156:880-891. https://doi.org/10.7326/00034819-156-12-201206190-00424

20. Schiffman M, Castle PE. The promise of global cervicalcancer prevention. N Engl J Med 2005;353:2101-2104. https://doi.org/10.1056/NEJMp058171

21. American Society for Colposcopy and Cervical Pathology. Algorithms: Updated Consensus Guidelines for Managing Abnormal Cervical Cancer Screening Tests and Cancer Precursors Available at: $\quad$ http://www.asccp.org/Assets/51b17a58-7af94667-879a3ff48472d6dc/635912165077730000/ asccpmanagementguidelines-august-2014-pdf. Accessed July 2016

22. Arora R, Malik A, Zutshi V, Bachani S. Comparison of cervicalbiopsy using punch biopsy forceps versus loop electrode. Int J Clin Biomed Res 2018;4:6-12. https:// doi.org/10.31878/ijcbr.2018.44.02"10.31878/ ijcbr.2018.44.02

Etik kurul onayı: Bu çalışma, Pamukkale Üniversitesi Girişimsel Olmayan Araştırmalar Klinik Etik Kurulu'nun 09.06.2020 tarih ve 11 sayılı kurul toplantısında görüşülerek etik açıdan sakınca olmadığına karar verilmiştir.

\section{Yazarların makaleye olan katkıları}

S.G., B.C.G. ve D.A.C. çalışmanın ana fikrini ve hipotezini kurgulamışlardır. S.G. ve D.A.C teoriyi geliştirmiş ve materyelmetod bölümünü düzenlemişlerdir. Sonuçlar kısmınındaki verilerin değerlendirmesini S.G. ve B.C.G. yapmışlardır. Makalenin tartışma bölümü S.G. tarafından yazılmış, B.C.G. gözden geçirip gerekli düzeltmeleri yapmış ve onaylamıştır. Ayrıca tüm yazarlar çalışmanın tamamını tartışmış ve son halini onaylamıştır. 